\title{
Autosomal dominant osteopetrosis type 1
}

INSERM

\section{Source}

INSERM. (1999). Orphanet: an online rare disease and orphan drug data base. Autosomal dominant osteopetrosis type 1. ORPHA:2783

Autosomal dominant osteopetrosis type I (ADO I) is a sclerosing bone disorder characterized by skeletal densification that predominantly involves the cranial vault. 